\title{
Distribution of Neuronal Receptors for Nerve Growth Factor in the Rat
}

\author{
P. M. Richardson, V. M. K. Verge Issa, and R. J. Riopelle \\ Division of Neurosurgery, McGill University, Montreal, Canada, and Division of Neurology, Queen's University, \\ Kingston, Canada
}

\begin{abstract}
To survey the distribution of neuronal receptors for NGF, sections of the rat brain, spinal cord, and peripheral ganglia were incubated in vitro with radioiodinated NGF and examined by autoradiography. NGF binds selectively with high affinity to most sympathetic neurons and many primary sensory neurons together with their intraspinal or intramedullary axons. In autoradiographs of the brain, labeled neuronal perikarya are seen in the basal forebrain, the caudate-putamen, the medulla oblongata, the ventral cochlear nucleus, and the dorsal nucleus of the lateral lemniscus. The distribution of neurons binding NGF resembles the distribution of cholinergic neurons in the forebrain, but these 2 systems overlap very little in the brain stem. In extracts of the brain or spinal cord enriched for plasma membranes, avid binding sites are regionally manifest with properties similar to those of fetal peripheral neurons. The localization of neurons expressing the high-affinity receptor for NGF defies simple correlation with neurotransmitter function or embryogenesis.
\end{abstract}

Interest in the possible functions of NGF in the CNS, as well as the PNS, has been aroused by 2 sets of observations. NGF and its mRNA have been found in the brain (Ayer-Le Lievre et al., 1983; Crutcher and Collins, 1982; Korsching et al., 1985; Shelton and Reichardt, 1984; Whittemore et al., 1985), and cholinergic neurons in the forebrain have been shown to respond to NGF (Gnahn et al., 1983; Honegger and Lenoir, 1982; Mobley et al., 1985). Because the major physiological actions of NGF are thought to be mediated through high-affinity neuronal receptors (Chandler et al., 1984; Sutter et al., 1979), putative sites of action of endogenous NGF are defined by the distribution of neurons with such receptors.

One established method for localizing neurons with NGF receptors involves selective uptake and retrograde axonal transport of radioiodinated NGF. In such studies, NGF is taken up avidly by sympathetic axons (Hendry et al., 1974), peripheral and central processes of sensory neurons (Richardson and Riopelle, 1984; Yip and Johnson, 1984), reticulocerebellar axons (Ebbott and Hendry, 1978), and axons projecting from basal forebrain to hippocampus or neocortex (Schwab et al., 1979; Seiler and Schwab, 1984). The retrograde transport method is applicable only to neurons with long axons and would require multiple injections for systematic mapping of NGF receptors.

In the past decade, autoradiographic techniques have been

\footnotetext{
Received Oct. 24, 1985; revised Jan. 31, 1986; accepted Feb. 5, 1986.

This work was supported by the Multiple Sclerosis Society of Canada and the Medical Research Council of Canada. We wish to thank Shizuye Faulkner for assistance in the binding studies and Evelyn Domond for helping to prepare the manuscript.

Correspondence should be addressed to P. M. Richardson, Division of Neurosurgery, Montreal General Hospital, 1650 Cedar Avenue, Montreal, Canada, H3G 1 A4.

Copyright (C) 1986 Society for Neuroscience $0270-6474 / 86 / 082312-10 \$ 02.00 / 0$
}

developed to display neurotransmitter receptors after incubation of tissue sections with appropriate radioligands (Herkenham and Pert, 1982; Wamsley and Palacios, 1983). This article describes an analogous procedure with radioiodinated NGF and surveys the distribution of NGF receptors in the rat PNS and CNS. Autoradiographic results are corroborated by steady-state binding studies with membrane-enriched preparations from selected regions of the brain and spinal cord. An independent study describing NGF-receptor autoradiography on embryonic chick tissues has recently been published (Raivich et al., 1985).

\section{Materials and Methods}

$\beta$-NGF, prepared from the submandibular glands of male mice by ionexchange chromatography (Chapman et al., 1981; Mobley et al., 1976), was radioiodinated by the lactoperoxidase method (Sutter et al., 1979), dialyzed for $24 \mathrm{hr}$ to remove unbound iodine, and passed through filters (Amicon CF50A) to remove aggregates. ${ }^{125}$ I-NGF with specific activity of $150-250 \mu \mathrm{Ci} / \mu \mathrm{g}$ was used within $72 \mathrm{hr}$ of preparation.

For autoradiography, female rats, 4-6 weeks old, were perfused per aorta with PBS, and specimens from the brain, spinal cord, or peripheral ganglia were removed and frozen in 2-methyl butane. Cryostat sections $10-20 \mu \mathrm{m}$ thick were mounted on gelatin-coated slides and stored 1-7 $\mathrm{d}$ at $-40^{\circ} \mathrm{C}$ before use. The incubation solution was prepared by diluting ${ }^{125} \mathrm{I}-\mathrm{NGF}$ to $40-80 \mathrm{pm}(1-2 \mathrm{ng} / \mathrm{ml})$ in $0.1 \mathrm{M}$ PBS, $\mathrm{pH} 7.4$, with magnesium chloride $(0.5 \mathrm{~mm})$, cytochrome c $(1 \mathrm{mg} / \mathrm{ml})$, leupeptin $4 \mu \mathrm{g} / \mathrm{ml})$, and phenylmethylsulfonylfluoride $(0.5 \mathrm{~mm})$. To distinguish specific and nonspecific binding, a 1000-fold excess of unlabeled NGF (40-80 nM) was included in some solutions. After incubation in coplin jars at $20^{\circ} \mathrm{C}$ for $90 \mathrm{~min}$, sections were rinsed briefly in 3 changes of cold PBS, fixed in $4 \%$ formaldehyde for $20 \mathrm{~min}$, rinsed in cold water to remove salts, and dried. The next day, sections were further fixed in formaldehyde vapor at $80^{\circ} \mathrm{C}$ for $2 \mathrm{hr}$ (Herkenham and Pert, 1982), defatted in a graded series of alcohols and xylene, rehydrated, dried, and dipped in radiosensitive emulsion (Kodak NTB2). The emulsion-coated slides were exposed in lightproof boxes at $4^{\circ} \mathrm{C}$ for $2-4 \mathrm{~d}$, developed in Kodak D-19, counterstained with thionin, and mounted (Permount). Five brains were used for mapping purposes, each with sections at 30-60 levels. Three rats were injected with di-isopropylffuorophosphate $(2 \mathrm{mg} / \mathrm{ml})$, and adjacent sections at 30-40 levels were prepared for cholinesterase histochemistry by a modification (Cochard and Coltey, 1983) of the technique of Karnovsky and Roots (1964) and for NGF receptor autoradiography. Autoradiographs were examined by light- and dark-field microscopy and the locations and outlines of labeled cells plotted through a drawing tube. Areas of cell bodies were measured with a digitizing tablet interfaced to a computer, and diameters of a circle of equal area were calculated. Dark-field photomicrographs at a final magnification of 600900 were used to count grains over cell bodies and background regions.

For binding studies, rats were perfused with PBS, and specimens from the spinal cord or brain were removed and frozen immediately. Fractions enriched for plasma membranes were prepared by a 2-phase polyethylene glycol dextran partition method (Riopelle et al., 1980) and stored at a concentration of $25-30 \mathrm{mg} / \mathrm{ml}$ at $-80^{\circ} \mathrm{C}$ until use. Steadystate binding studies were carried out with $12-15 \mathrm{mg}$ membrane protein plus ${ }^{125}$ I-NGF at $2-200$ pM in $450 \mu$ l of phosphate-buffered Gey's balanced salt solution with BSA $(1 \mathrm{mg} / \mathrm{ml})$. After incubation at $4^{\circ} \mathrm{C}$ with continuous mixing for 16-24 hr, bound and free ligand were separated by centrifugation of $100 \mu \mathrm{l}$ aliquots $(10,000 \times g$ for $2 \mathrm{~min})$, and gamma 

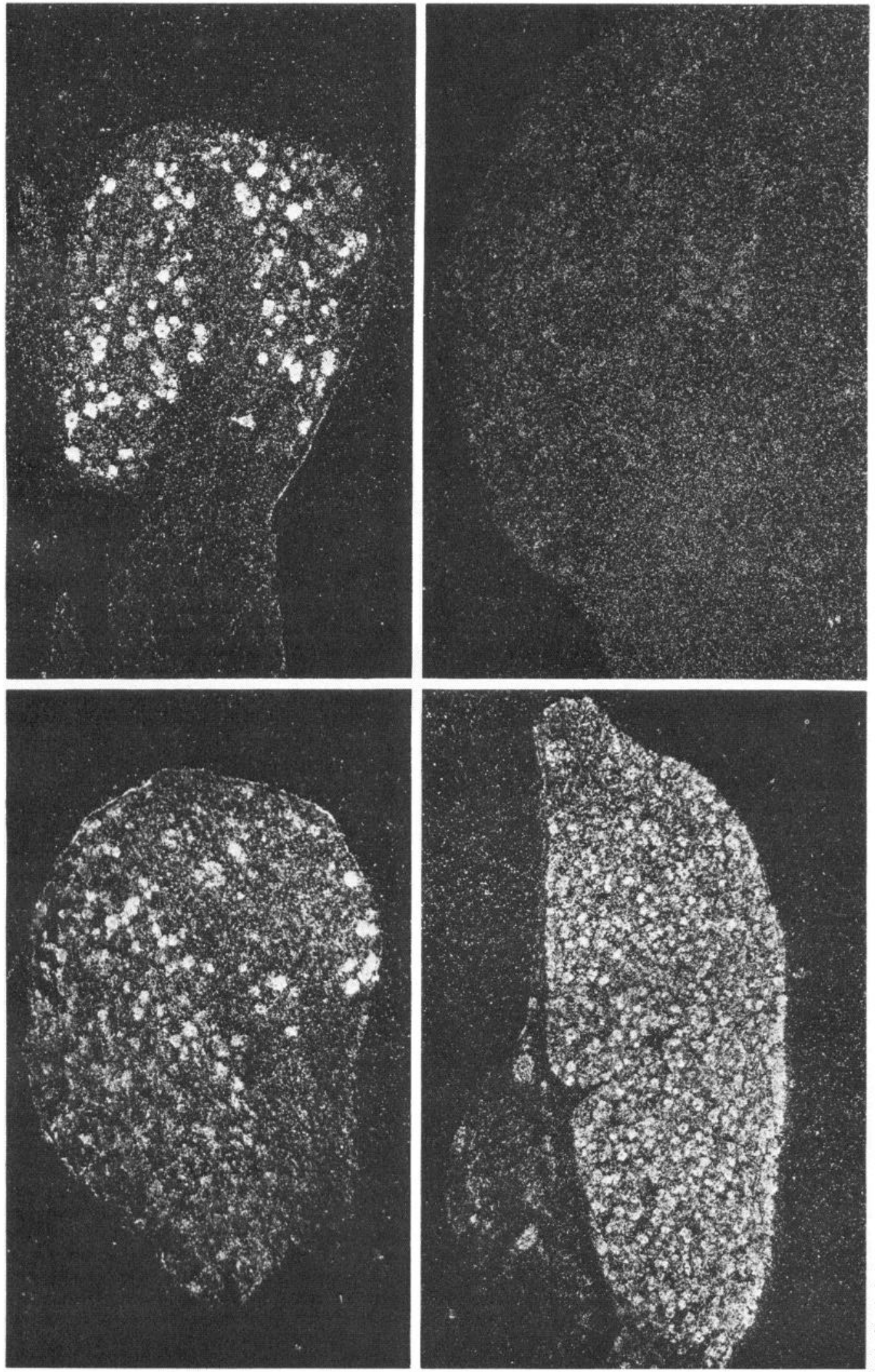

Figure 1. Dark-field photomicrographs of autoradiographs from the same animal incubated with ${ }^{125} \mathrm{I}-\mathrm{NGF}$ at 50 pM. $\times 50$. Upper left, L5 DRG. Approximately $45 \%$ of all neuronal perikarya are labeled. Upper right, L5 DRG. Labeling over neurons is almost completely suppressed by unlabeled NGF at $40 \mathrm{~nm}$. Lower left, Nodose ganglia. Labeling is intense over some neurons but also above background over many other neurons. Lower right, Sympathetic ganglia. Most, if not all, neurons are labeled.

activity was counted in the pellets (Riopelle et al., 1980). Long incubation times were found to be necessary to ensure equilibrium conditions with low concentrations of radioiodinated NGF. Degradation of ${ }^{125}$ I-NGF was assumed to be negligible, as in earlier binding studies with membrane-enriched fractions (Riopelle et al., 1980).

\section{Results}

In autoradiographs, neuronal cell bodies were unequivocally labeled in sensory and sympathetic ganglia and in discrete regions of the brain. The grain counts associated with all central 


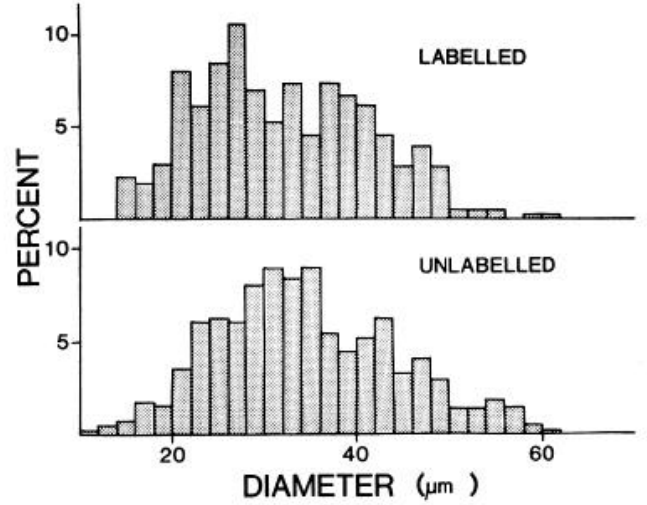

Figure 2. Diameters of samples of labeled and unlabeled neurons in the L5 DRG. Means $( \pm \mathrm{SD})$ are $32.1 \pm 9.5(n=427)$ and $34.4 \pm 9.8(n=$ 442), respectively.

and peripheral neurons were reduced nearly to background levels when cold NGF at $40-80 \mathrm{~nm}$ was included in the medium. Additional labeling in other regions of the brain and spinal cord, not over cell bodies, was presumed to overlie nerve fibers.

\section{Peripheral ganglia}

Superior cervical ganglia, fifth lumbar dorsal root ganglia (L5 DRG), trigeminal ganglia, and nodose ganglia were examined; all were found to contain labeled neurons (Fig. 1). Within sympathetic ganglia, virtually all neurons bound NGF specifically. In L5 DRG, labeled neurons (40-45\%) and unlabeled neurons were intermingled without apparent clustering or topographical pattern. Heavily labeled and unlabeled neurons could usually be clearly distinguished; little gradation of grain densities was apparent. The mean diameter of labeled neurons was only slightly less than that for unlabeled neurons, but relatively few neurons with diameter $>50 \mu \mathrm{m}$ were labeled (Fig. 2). In nodose ganglia, approximately one-quarter of neurons were heavily labeled.

\section{Spinal cord}

In sections of the thoracic and lumbar spinal cord (Fig. 3), a band of silver grains was associated with layers I and II of the dorsal horn (Rexed, 1952), and patches were found in layer III. This labeling was suppressed by unlabeled NGF at $40 \mathrm{nM}$ in the incubation medium and ipsilaterally diminished when 4 dorsal roots on one side were avulsed 1 week before sacrifice. No labeled perikarya were seen in the spinal cord.

\section{Brain stem}

Most labeled neurons in the brain stem were concentrated in 3 regions (Table 1, Figs. 4 and 5). In the medulla oblongata, a conspicuous collection of large neurons was seen under the fourth ventricle in the prepositus hypoglossi and suprageniculate nuclei and extended caudally, ventrally, and laterally into the paramedian and gigantocellular reticular nuclei. Smaller labeled neurons were found in all rats within the ventral cochlear nucleus and dorsal nucleus of the lateral lemniscus. Cytological definition in these frozen sections was not adequate to ascertain what class of cochlear neurons was labeled. Silver grains were concentrated over an occasional small neuron near the mesencephalic trigeminal nucleus but not in any large neuron of this nucleus. The pedunculopontine tegmental nucleus and laterodorsal tegmental nucleus were examined closely because they are rich in cholinesterase-positive neurons but not more than 2 NGF-binding neurons were found in any single section through these nuclei. Finally, a small group of large labeled neurons was seen near the midline in the pontine reticular formation.

Silver grains were also associated with the tract of the spinal trigeminal nucleus (Fig. 5) and the interpeduncular region. For both of these areas, counts were reduced to background levels by unlabeled NGF at $40 \mathrm{~nm}$.

\section{Forebrain}

Contiguous patches of labeled neurons were seen in the medial septal nucleus, diagonal band of Broca, lateral preoptic area, and ventrocaudal globus pallidus (Table 1, Figs. 5-7). Examination of adjacent sections through 3 basal forebrains showed that the distributions of NGF-labeled neurons and strongly cholinesterase-positive neurons were very similar (Fig. 8). Although quantitative studies were not done, these 2 populations also resembled each other in regional cell density and perikaryal size. A single attempt at double-labeling sections for cholinesterase and the NGF receptor was unsuccessful. Labeled neurons, slightly larger than most neostriatal neurons, were scattered homogenously throughout the caudate-putamen with approximately the same density as cholinergic neurons.

Silver grains were also found in 2 elliptical bands over the hippocampus proper and area dentata. Unlike all the other regions discussed, binding in the hippocampus was only slightly reduced by unlabeled NGF at $40 \mathrm{~nm}$ and incompletely suppressed even at $400 \mathrm{~nm}$.

\section{Binding studies}

Scatchard analysis of steady-rate binding studies with preparations enriched for plasma membranes revealed NGF-binding sites with a dissociation equilibrium constant of 10-40 pм in the dorsal third of the spinal cord, caudate-putamen (Fig. 9), basal forebrain, and hippocampus. Eight studies were done with

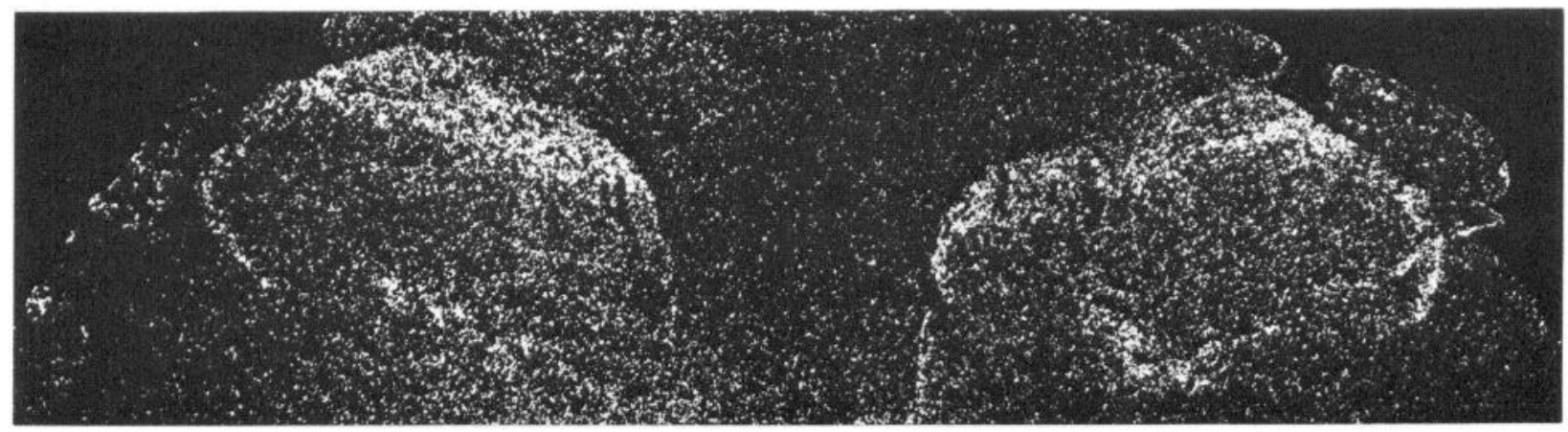

Figure 3. Montage of dorsal third of lumbar spinal cord following incubation with ${ }^{125} \mathrm{I}-\mathrm{NGF}$ at $80 \mathrm{pM}$. Grains are concentrated over layers I and II and parts of layer III in the dorsal horn. $\times 50$. 


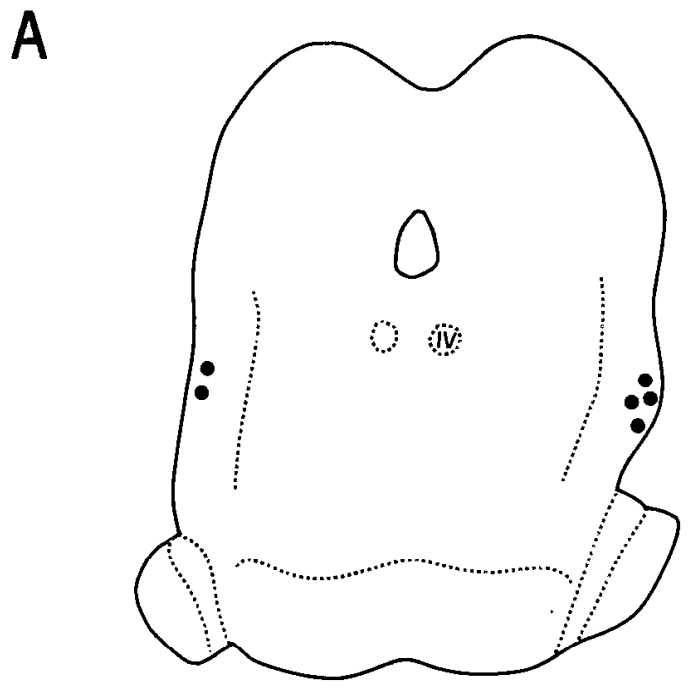

B
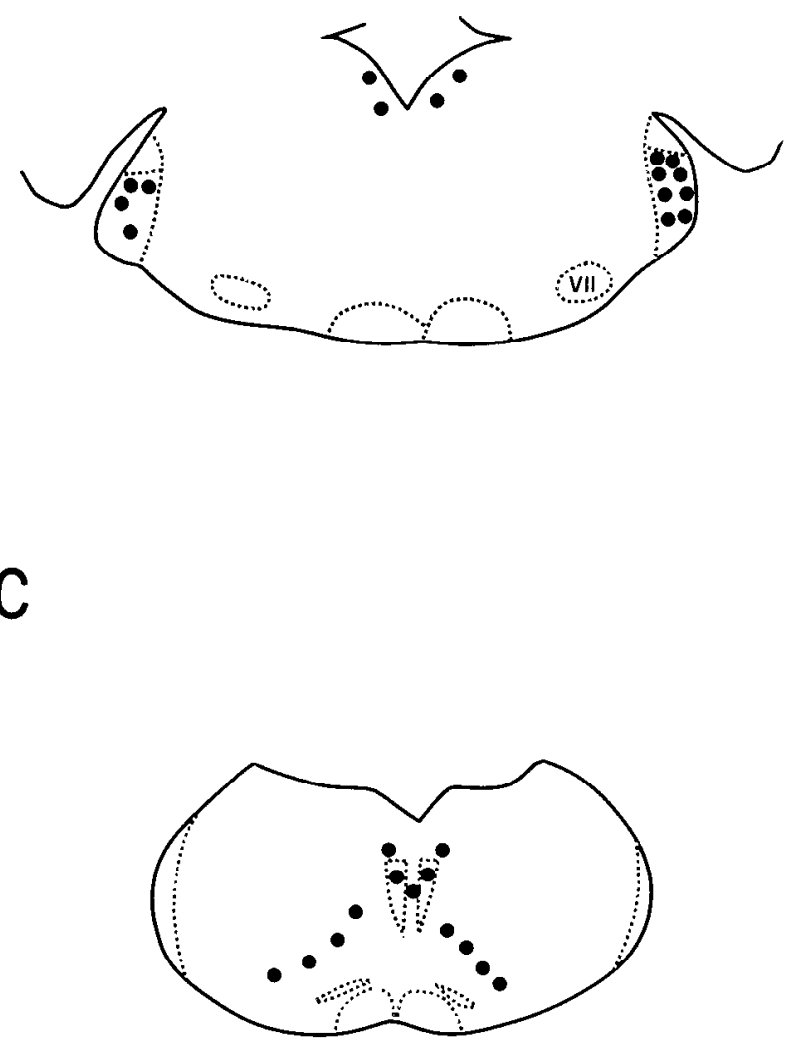

Figure 4. Major collections of NGF-binding neurons in the brain stem. Each dot represents 5 labeled neurons. They are found in the dorsal nucleus of the lateral lemniscus $(A)$, nucleus prepositus hypoglossi $(B)$, ventral cochlear nucleus $(B)$, paramedian plus gigantocellular reticular nuclei in the medulla oblongata $(C)$, and interpeduncular region (not shown).

preparations from the basal forebrain, yielding a dissociation equilibrium constant of $16 \pm 8$ pM (mean \pm SEM). Additional binding of NGF at lower affinity was also seen in many regions studied but has not yet been fully characterized. With these
Table 1. Size and labeling index for NGF-binding neurons

\begin{tabular}{lll} 
Nucleus & $\begin{array}{l}\text { Neuronal diameter } \\
(\mu \mathrm{m})\end{array}$ & Labeling index \\
\hline Medullary reticular & $26.9 \pm 3.0$ & $2.8 \pm 1.0$ \\
Ventral cochlear & $19.4 \pm 2.5$ & $3.1 \pm 0.9$ \\
Lateral lemniscal & $16.9 \pm 4.4$ & n.a. \\
Diagonal band & $23.5 \pm 4.5$ & $3.0 \pm 1.1$ \\
Globus pallidus & $25.6 \pm 4.5$ & $4.2 \pm 1.2$ \\
Caudate-putamen & $22.6 \pm 2.6$ & $2.3 \pm 0.7$
\end{tabular}

The labeling index refers to the ratio of grain densities over cell bodies and background regions. Means \pm SD are given.

methods, high-affinity binding sites were not evident in extracts from the cerebellum or thalamus.

\section{Discussion}

\section{Technical considerations}

Most clusters of large neurons in the brain with high-affinity NGF receptors have probably been detected in this survey, but small or scattered neurons may have been missed. On darkfield examination, neurons are relatively inconspicuous if diffuse, as in the caudate, or small, as in the cochlear nucleus. The present autoradiographic technique also fails to detect some NGF receptors known to be present on nerve fibers or terminals. For example, high-affinity receptors on sensory and sympathetic axons in peripheral nerves are not visualized, perhaps because they are masked by low-affinity binding sites on Schwann cells (Ross et al., 1984; Zimmermann and Sutter, 1983). Also, NGF receptors, which are presumably present on cholinergic terminals in the cerebral cortex (Seiler and Schwab, 1984), are not manifest in any of the autoradiographs. The sensitivity of the technique can perhaps be increased by further technical refinements to reduce nonspecific binding.

Binding sites with a dissociation equilibrium constant of approximately 20 pM are found in the rat CNS, as in chick sensory neurons (Sutter et al., 1979) and tumor cells of neural crest origin (Lyons et al., 1983). High-affinity receptors on central and peripheral neurons are presumably the same, or very similar, molecules. Less avid binding with dissociation equilibrium constant in the nanomolar range is described in the brain (Frazier et al., 1974), and receptors of this lower affinity have been characterized from cultured melanoma and pheochromocytoma cells (Grob et al., 1985; Hosang and Shooter, 1985; Puma et al., 1983). After incubation of sections with ${ }^{125}$ I-NGF at 60 pM, approximately $75 \%$ of high-affinity receptors and $3 \%$ of lowaffinity receptors should be occupied. Thus, the autoradiographic conditions, chosen to be optimal for high-affinity binding sites, are not appropriate for localizing low-affinity receptors.

\section{Correlation with retrograde transport studies}

The present results confirm and extend previous localizations of neurons with NGF receptors by retrograde tracing methods. When neurons in the L5 DRG are exposed to ${ }^{125} \mathrm{I}-\mathrm{NGF}$ either by intraneural injection in vivo (Richardson and Riopelle, 1984) or incubation of sections in vitro (Fig. 2), 35-45\% of the total population is selectively labeled with ${ }^{125} \mathrm{I}-\mathrm{NGF}$. The proportion is slightly lower in retrograde transport studies than with autoradiography in vitro, probably because not all L5 DRG neurons project to the sciatic nerve. Neurons in the diagonal band of Broca and globus pallidus of rats have been retrogradely labeled from the hippocampus or neocortex (Schwab et al., 1979; Seiler and Schwab, 1984), and NGF-binding neurons in the lateral preoptic area can reasonably be assumed to project to 

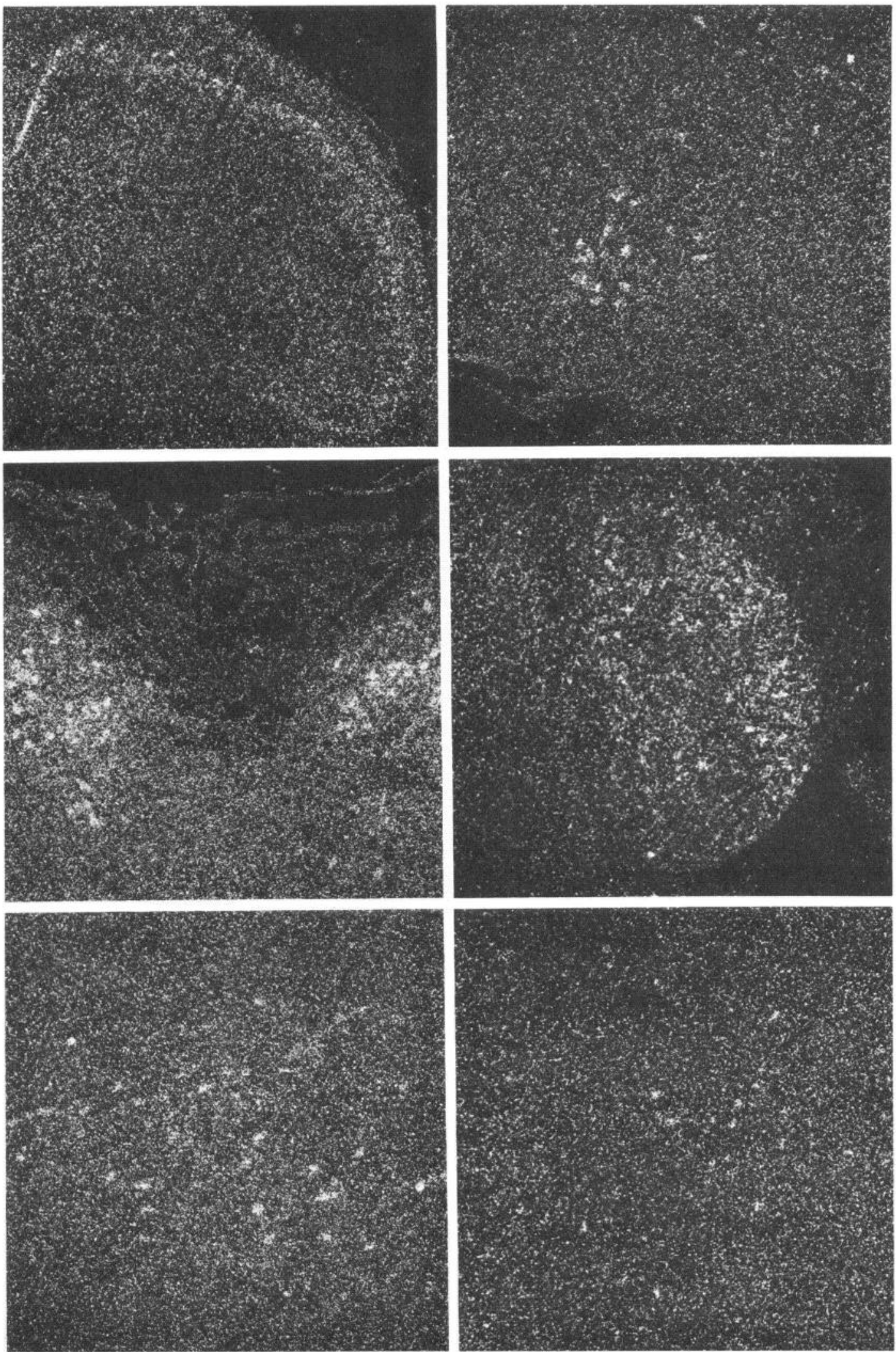

Figure 5. Dark-field photomicrographs of autoradiographs prepared from sections of the brain incubated with ${ }^{125} \mathrm{I}-\mathrm{NGF}$ at $40-80 \mathrm{pM} . \times 50$. Upper left, Tract of the spinal trigeminal nucleus. Upper right, Gigantocellular reticular nucleus. The ventral border of medulla oblongata is seen at lower left. Middle left, Near the nucleus prepositus hypoglossi beneath the fourth ventricle. Middle right, Ventral cochlear nucleus. The dorsal cochlear nucleus is unlabeled. Lower left, The ventrocaudal region of the globus pallidus. Lower right, The caudate. Labeling of scattered neurons is consistently seen in autoradiographs of the neostriatum. 
A

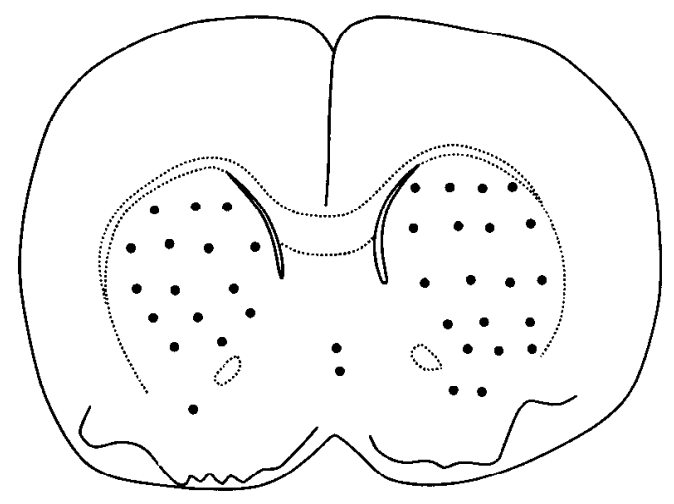

C

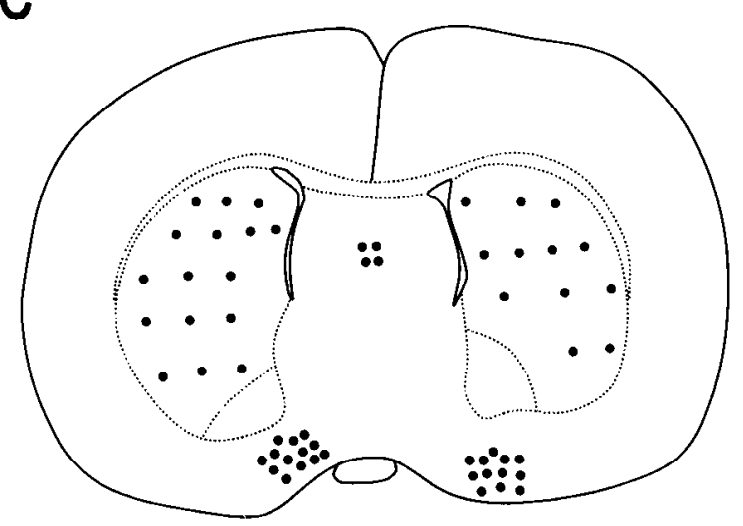

E

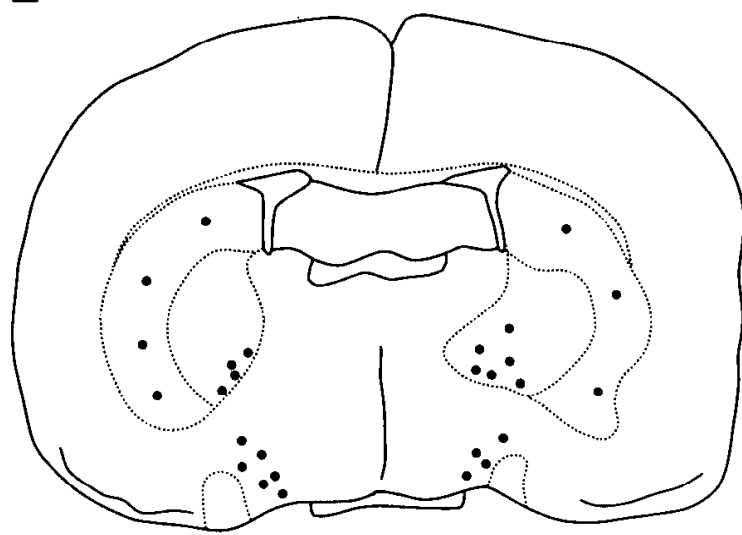

B



D

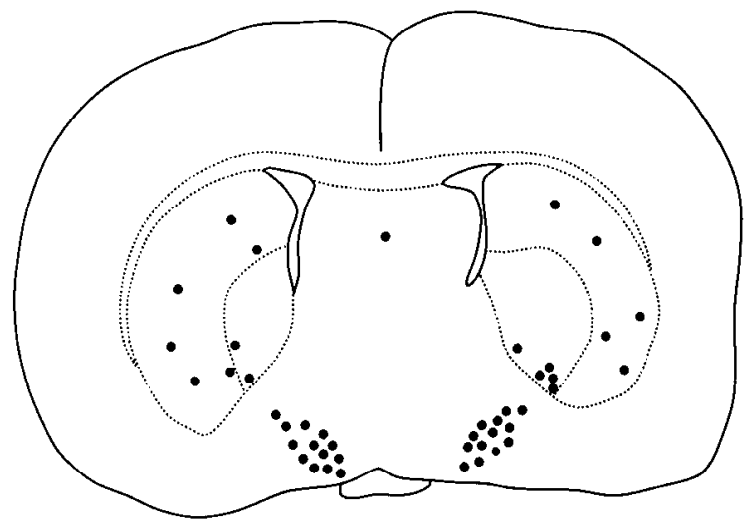

F



Figure 6. Major collections of NGF-binding neurons in the forebrain. Each dot represents 5 labeled neurons. They are found in the caudateputamen $(A-F)$, diagonal band of Broca $(A, B)$, medial septal nucleus $(C, D)$, lateral preoptic area $(C-E)$, and globus pallidus $(D-F)$. The last 4 areas coincide with cholinergic fields Chl-4 (Mesulam et al., 1983).

the olfactory bulb (Mesulam et al., 1983). If neurons in the neostriatum that bear NGF receptors are indeed cholinergic, it is not surprising that they have escaped detection by retrograde transport studies, because most cholinesterase-positive neurons in the caudate-putamen are probably interneurons with short axons (Woolf and Butcher, 1981). Some neurons in the brain stem with NGF receptors probably project to the cerebellum (Brodal, 1952; Ebbott and Hendry, 1978).

\section{Do all neuronal NGF receptors have a function?}

NGF is synthesized endogenously in the hippocampus (Shelton and Reichardt, 1984), is retrogradely transported in septohippocampal axons (Seiler and Schwab, 1984), and is capable of inducing cholinergic enzymes in the basal forebrain when administered exogenously (Gnahn et al., 1983; Honegger and Lenoir, 1982; Mobley et al., 1985). In general, the distribution of 


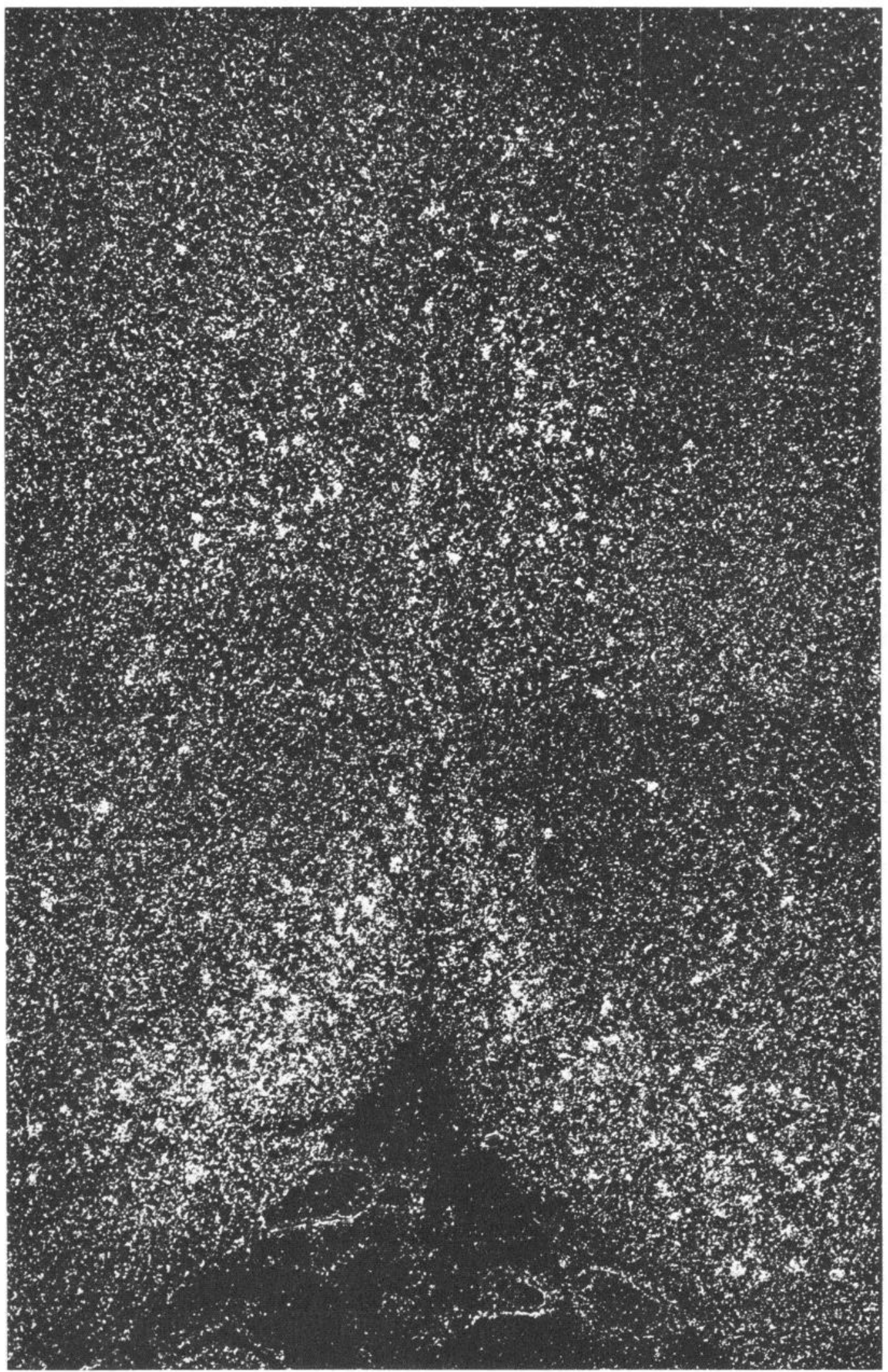

Figure 7. Montage of dark-field photomicrographs showing neurons in the diagonal band of Broca labeled by 40 pM ${ }^{125}$ I-NGF. $\times 80$.

mRNA for NGF in the forebrain (Korsching et al., 1985; Whittemore et al., 1985) is correlated with the projection fields of receptor-bearing neurons in the basal forebrain. These observations provide strong circumstantial evidence that NGF is involved in the development and/or maintenance of cholinergic neurons in the forebrain.

Whether NGF receptors have a function in the spinal cord remains an open question. The mere presence of NGF receptors 

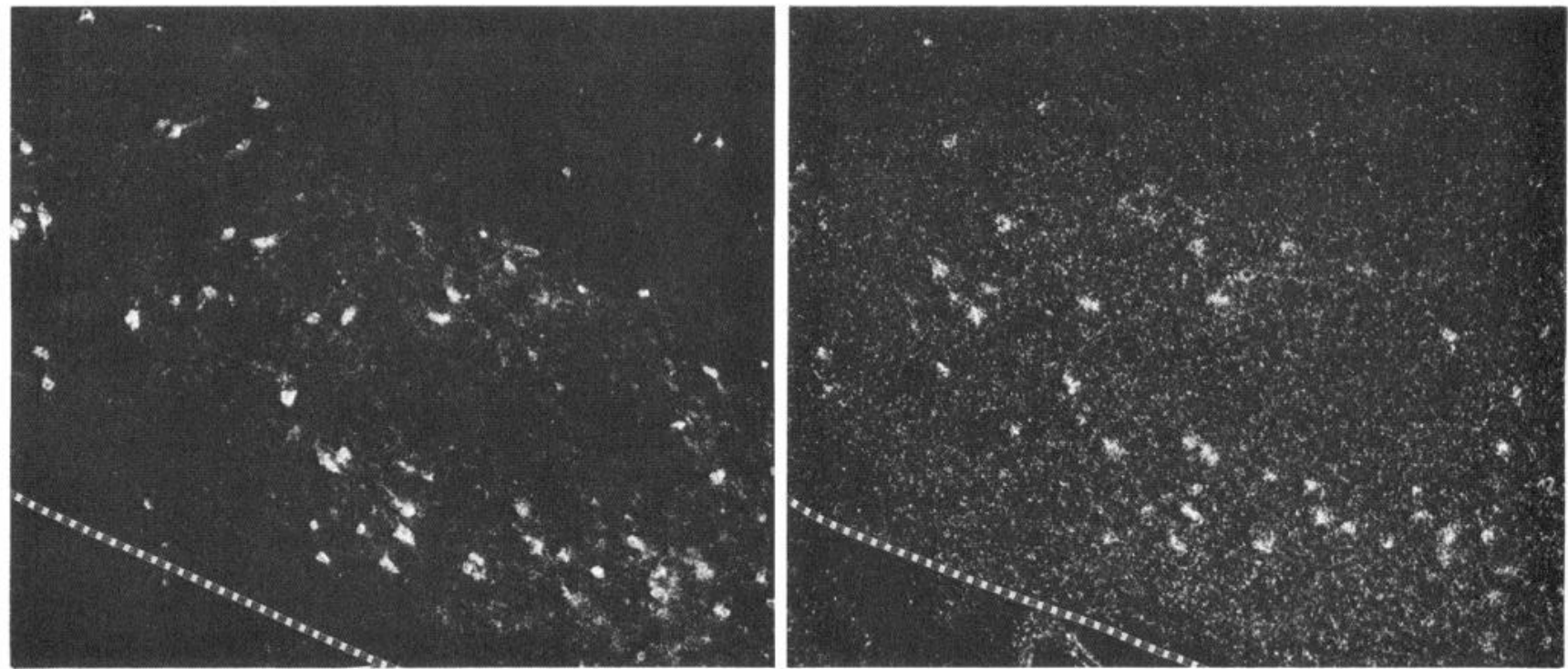

Figure 8. Adjacent sections through the horizontal limb of the diagonal band of Broca processed for cholinesterase histochemistry (left) and NGFreceptor autoradiography (right). The distributions and densities of labeled neurons are similar; neuronal sizes cannot be accurately compared because of differences in photographic technique. $\times 60$.

in the spinal cord cannot be taken as evidence that endogenous NGF acts there, because ligands and their receptors are often mismatched (Kuhar, 1985). No mechanism has been recognized for selective axonal transport or membrane insertion of NGF receptors in the 2 processes of primary sensory neurons. NGF receptors along sensory axons in spinal roots or peripheral nerves probably interact with NGF released from peripheral sheath cells (Richardson and Ebendal, 1982; Riopelle et al., 1981; Rush, 1984; Shelton and Reichardt, 1984). NGF receptors in the spinal cord may encounter no endogenous ligand.

Although high-affinity NGF receptors are undoubtedly present in nodose neurons (Fig. 1), the actions of NGF on these neurons are still unclear (Davies and Lindsay, 1985; Hedlund and Ebendal, 1980).

\section{$N G F$ receptors and neurotransmitter function}

In the basal forebrain and neostriatum, neurons that specifically bind ${ }^{125}$ I-NGF (Figs. 6, 7) bear a striking resemblance to cholinergic neurons (Armstrong et al., 1983; Mesulam et al., 1983) in cytology, density, and distribution. Double labeling on the same section to study rigorously the co-expression of cholinergic enzymes and the NGF receptor will be technically difficult: Tissue should be unfixed for receptor autoradiography and fixed for cholineacetyltransferase immunohistochemistry or cholinesterase histochemistry. In the brain stem, correlation between cholinergic phenotype and NGF binding breaks down. Many neurons in the pontomesencephalic tegmentum are cholinergic (Armstrong et al., 1983; Mesulam et al., 1983) yet lack NGF
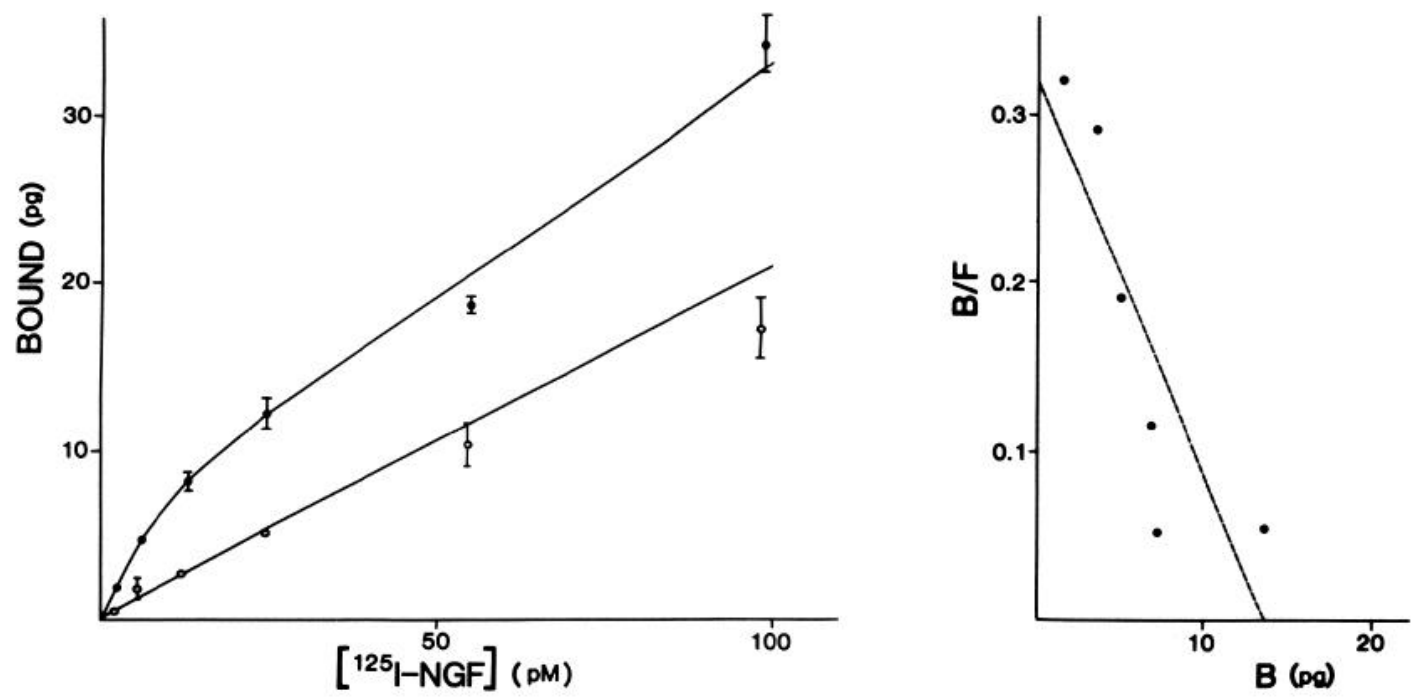

Figure 9. Left, Binding of ${ }^{125} \mathrm{I}-\mathrm{NGF}$ to extracts of the caudate-putamen enriched for plasma membranes. Each aliquot contained 0.3 mg protein in a volume of $100 \mu \mathrm{l}$. $\bullet$, Total binding; $O$, binding in the presence of unlabeled NGF, $40 \mathrm{pM}$. The straight line through the lower points was fitted by weighted least squares. Some "nonspecific" binding was truly low-affinity binding because it could be further suppressed by higher concentrations of unlabeled NGF. Right, Scatchard plot of the same data. B, Represents the difference between total binding and binding in the presence of unlabeled NGF, $40 \mathrm{nM}$. Fitting a straight line by the least-squares method gave $K_{\mathrm{d}}=16 \mathrm{pM}, B_{\max }=1.5 \mathrm{fmol} / \mathrm{mg}$ protein; fitting of the curve of $B$ vs $F$ to a hyperbola gave $K_{\mathrm{d}}=21 \mathrm{pM}, B_{\max }=1.8 \mathrm{fmol} / \mathrm{mg}$ protein. 
receptors; NGF-binding neurons and cholinergic neurons are not identically distributed in the medulla oblongata. The hypothesis that neurons with NGF receptors are invariably cholinergic is tenable (albeit unproved) for the telencephalon but is clearly invalid elsewhere in the brain.

In sensory ganglia, even the limited information available appears to preclude a simple relationship between neuropeptide content of neurons and their ability to bind NGF. For example, some neurons with NGF receptors probably contain substance P or somatostatin (Goedert et al., 1984), but most large neurons with NGF receptors (Fig. 2) probably do not contain either (Price, 1985). It remains to be seen if the NGF receptor is preferentially distributed on subclasses of sensory neurons that have been defined by immunohistochemistry (Dodd and Jessell, 1985).

Most catecholaminergic neurons in sympathetic ganglia bear NGF receptors; most catecholaminergic neurons in the locus ceruleus do not.

The several populations of peripheral and central neurons that are potentially responsive to NGF are heterogenous in their neurotransmitter function.

\section{NGF receptor as a developmental marker}

In these autoradiographic studies, the high-affinity NGF receptor does not appear to be a specific or infallible marker for cells of ncural crest origin. NGF binds avidly to neurons in nodose ganglia, the medulla oblongata, the basal forebrain, and the striatum - none of which are commonly believed to originate from the neural crest (Ayer-Le Lievre and Le Douarin, 1982; Le Douarin, 1980; Weston, 1970). Conversely, more than half of the neurons in spinal ganglia lack high-affinity receptors, even though all these primary sensory neurons are thought to have migrated from the neural crest (Le Douarin, 1980; Weston, 1970).

Expression of the NGF receptor may be influenced by NGF itself (Landreth and Shooter, 1980; Rohrer and Barde, 1982) or other environmental factors, rather than immutably determined by clonal origin or cell lineage. The presently inexplicable distribution of the NGF receptor among and within groups of neurons begs some unifying concept of its genesis and function in development.

\section{References}

Armstrong, D. M., C. B. Saper, A. I. Levey, B. H. Wainer, and R. D. Terry (1983) Distribution of cholinergic neurons in rat brain: Demonstrated by the immunocytochemical localization of choline acetyltransferase. J. Comp. Neurol. 216: 53-68.

Ayer-Le Lievre, C. S., and N. M. Le Douarin (1982) The early development of cranial sensory ganglia and the potentialities of their component cells studied in quail-chick chimeras. Dev. Biol. 94: 291310.

Ayer-Le Lievre, C. S., T. Ebendal, L. Olson, and A. Seiger (1983) Localization of nerve growth factor-like immunoreactivity in rat nervous tissue. Med. Biol. 61: 296-304

Brodal, A. (1952) Experimental demonstration of cerebellar connexions from the peri-hypoglossal nuclei in the cat. J. Anat. $86: 110-$ 129.

Chandler, C. E., L. M. Parsons, M. Hosang, and E. M. Shooter (1984) A monoclonal antibody modulates the interaction of nerve growth factor with PC12 cells. J. Biol. Chem. 259: 6882-6889.

Chapman, C. A., B. E. C. Banks, C. A. Vernon, and J. M. Walker (1981) The isolation and characterisation of nerve growth factor from the prostate gland of the guinea-pig. Eur. J. Biochem. 115: 347-351.

Cochard, P., and P. Coltey (1983) Cholinergic traits in the neural crest: Acetylcholinesterase in crest cells of the chick embryo. Dev. Biol. 98 221-238.

Crutcher, K. A., and F. Collins (1982) In vitro evidence for two distinct hippocampal growth factors: Basis of neuronal plasticity? Science 217: $67-68$.

Davies, A. M., and R. M. Lindsay (1985) The cranial sensory ganglia in culture: Differences in the response of placode-derived and neural crest-derived neurons to nerve growth factor. Dev. Biol. 111: 62-72.

Dodd, J., and T. M. Jessell (1985) Lactoseries carbohydrates specify subsets of dorsal root ganglion neurons projecting to the superficial horn of the spinal cord. J. Neurosci. 5: 3278-3294.

Ebbott, S., and I. Hendry (1978) Retrograde transport of nerve growth factor in the rat central nervous system. Brain Res. 139: 160-163.

Frazier, W. A., L. F. Boyd, M. W. Pulliam, A. Szutowicz, and R. A. Bradshaw (1974) Properties and specificity of binding sites for ${ }^{125} \mathrm{I}-$ nerve growth factor in embryonic heart and brain. J. Biol. Chem. 249: 5918-5923.

Gnahn, H., F. Hefti, R. Heumann, M. E. Schwab, and H. Thoenen (1983) NGF-mediated increase of choline acetyltransferase (ChAT) in the neonatal rat forebrain: Evidence for a physiological role of NGF in the brain? Dev. Brain Res. 9: 45-52.

Goedert, M., U. Otten, S. P. Hunt, A. Bond, D. Chapman, M. Schlumpf, and W. Lichtensteiger (1984) Biochemical and anatomical effects of antibodies against nerve growth factor on developing rat sensory ganglia. Proc. Natl. Acad. Sci. USA 81: 1580-1584.

Grob, P. M., A. H. Ross, H. Koprowski, and M. Bothwell (1985) Characterization of the human melanoma nerve growth factor receptor. J. Biol. Chem. 260: 8044-8049.

Hedlund, K.-O., and T. Ebendal (1980) The chick embryo nodose ganglion: Effects of nerve growth factor in culture. J. Neurocytol. 9: $665-682$.

Hendry, I. A., K. Stöckel, H. Thoenen, and L. L. Iversen (1974) The retrograde axonal transport of nerve growth factor. Brain Res. 68 . 103-121.

Herkenham, M., and C. B. Pert (1982) Light microscopic localization of brain opiate receptors: A general autoradiographic method which preserves tissue quality. J. Neurosci. 2: 1129-1149.

Honegger, P., and D. Lenoir (1982) Nerve growth factor (NGF) stimulation of cholinergic telencephalic neurons in aggregating cell cultures. Dev. Brain Res. 3: 229-238.

Hosang, M., and E. M. Shooter (1985) Molecular characteristics of nerve growth factor receptors on PC12 cells. J. Biol. Chem. 260:655662.

Karnovsky, M. J., and L. Roots (1964) A "direct-coloring" thiocholine method for cholinesterases. J. Histochem. Cytochem. 12: 219-221.

Korsching, S., G. Auburger, R. Heumann, J. Scott, and H. Thoenen (1985) Levels of nerve growth factor and its mRNA in the central nervous system of the rat correlate with cholinergic innervation. EMBO J. 4: 1389-1394.

Kuhar, M. J. (1985) The mismatch problem in receptor mapping studies. TINS $8:$ 190-191.

Landreth, G. E., and E. M. Shooter (1980) Nerve growth factor receptors on PC12 cells: Ligand-induced conversion from low- to highaffinity states. Proc. Natl. Acad. Sci. USA 77: 4751-4755.

Le Douarin, N. M. (1980) The ontogeny of the neural crest in avian embryo chimaeras. Nature 286: 663-669.

Lyons, C. R., R. W. Stach, and J. R. Perez-Polo (1983) Binding properties of isolated NGF-receptors from different species. Biochem. Biophys. Res. Commun. 115: 368-374.

Mesulam, M.-M., E. J. Mufson, B. H. Wainer, and A. I. Levey (1983) Central cholinergic pathways in the rat: An overview based on an alternative nomenclature (Ch1-Ch6). Neuroscience 10: 1185-1201.

Mobley, W. C., A. Schenker, and E. M. Shooter (1976) Charactcrization and isolation of proteolytically modified nerve growth factor. Biochemistry 15: 5543-5551.

Mobley, W. C., J. L. Rutkowski, G. I. Tennekoon, K. Buchanan, and M. V. Johnston (1985) Choline acetyltransferase activity in striatum of neonatal rats increased by nerve growth factor. Science 229: 284 287.

Price, J. (1985) An immunohistochemical and quantitative examination of dorsal root ganglion neuronal subpopulations. J. Neurosci. 5.2051-2059.

Puma, P., S. E. Buxser, L. Watson, D. J. Kelleher, and G. L. Johnson (1983) Purification of the receptor for nerve growth factor from A875 melanoma cells by affinity chromatography. J. Biol. Chem. 258: 33703375.

Raivich, G., A. Zimmermann, and A. Sutter (1985) The spatial and temporal pattern of $\beta$ NGF receptor expression in the developing chick embryo. EMBO J. 4: 637-644.

Rexed, B. (1954) A cytoarchitectonic atlas of the spinal cord in the cat. J. Comp. Neurol. 100: 297-379. 
Richardson, P. M., and T. Ebendal (1982) Nerve growth activities in rat peripheral nerve. Brain Res. 246: 57-64.

Richardson, P. M., and R. J. Riopelle (1984) Uptake of nerve growth factor along peripheral and spinal axons of primary sensory neurons. J. Neurosci. 4: 1683-1689.

Riopelle, R. J., M. Klearman, and A. Sutter (1980) Nerve growth factor receptors: Analysis of the interaction of $\beta$ NGF with membranes of chick embryo dorsal root ganglia. Brain Res. 199: 63-77.

Riopelle, R. J., R. J. Boegman, and D. A. Cameron (1981) Peripheral nerve contains heterogeneous growth factors that support sensory neurons in vitro. Neurosci. Lett. 25: 311-316.

Rohrer, H., and Y.-A. Barde (1982) Presence and disappearance of nerve growth factor receptors on sensory neurons in culture. Dev. Biol. 89: 309-315.

Ross, A. H., P. Grob, M. Bothwell, D. E. Elder, C. S. Ernst, N. Marano B. F. D. Ghrist, C. C. Slemp, M. Herlyn, B. Atkinson, and H. Koprowski (1984) Characterization of nerve growth factor receptor in neural crest tumors using monoclonal antibodies. Proc. Natl. Acad. Sci. USA 81: 6681-6685.

Rush, R. A. (1984) Immunohistochemical localization of endogenous nerve growth factor. Nature 312: 364-367.

Schwab, M. E., U. Otten, Y. Agid, and H. Thoenen (1979) Nerve growth factor (NGF) in the rat CNS: Absence of specific retrograde axonal transport and tyrosine hydroxylase induction in locus coeruleus and substantia nigra. Brain Res. 168: 473-483.

Seiler, M., and M. E. Schwab (1984) Specific retrograde transport of nerve growth factor (NGF) from neocortex to nucleus basalis in the rat. Brain Res. 300: 33-39.

Shelton, D. L., and L. F. Reichardt (1984) Expression of the $\beta$-nerve growth factor gene correlates with the density of sympathetic innervation in effector organs. Proc. Natl. Acad. Sci. USA 81: 7951-7955.

Sutter, A., R. J. Riopelle, R. M. Harris-Warrick, and E. M. Shooter (1979) Nerve growth factor receptors. J. Biol. Chem. 254: 59725982.

Wamsley, J. K., and J. M. Palacios (1983) Apposition techniques of autoradiography for microscopic receptor localization. In Current Methods in Cellular Neurobiology. J. L. Barker and J. F. McKelvy, eds., pp. 241-268, Wiley, New York.

Weston, J. (1970) The migration and differentiation of neural crest cells. Adv. Morphogenes. 8: 41-114.

Whittemore, S. R., T. Ebendal, L. Lärkfors, L. Olson, A. Seiger, I. Strömberg, and H. Persson (1985) Developmental, regional and post-lesion expression of nerve growth factor (NGF) and NGF mRNA in rat brain. Soc. Neurosci. Abstr. 11: 660 .

Woolf, N. J., and L. L. Butcher (1981) Cholinergic neurons in the caudate-putamen complex proper are intrinsically organized: A combined Evans Blue and acetylcholinesterase analysis. Brain Res. Bull. 7: 487-507.

Yip, H. K., and E. M. Johnson, Jr. (1984) Developing dorsal root ganglion neurons require trophic support from their certral processes: Evidence for a role of retrogradely transported nerve growth factor from the central nervous system to the periphery. Proc. Natl. Acad. Sci. USA 81: 6245-6249.

Zimmermann, A, and A. Sutter (1983) $\beta$-Nerve growth factor ( $\beta$ NGF) receptors on glial cells. Cell-cell interaction between neurones and Schwann cells in cultures of chick sensory ganglia. EMBO J. 2: 879885 . 